\author{
M.G. BARDET \\ Consulting Geologist, BRGM \\ 26, rue Jean Giraudoux - PARIS - 16e
}

The petrographic features of all Kimberlites are the same all over the world, and independantly of their age : Precambrian Premier kimberlite, Paleozolc ones from Yakutia or the Cretaceous kimberlites from everywhere are similar. Yet, during the last years, some rather deceiving Precambrian kimberlites had been found near Seguela (Ivory Coast), and Mitzic, (Gabon), which I propose to call "Metakimberlites" to distinguish them, for their unusual features, from the "classic" kimberlites. Their macroscopic aspect is different as they often look like talcschists or micaschists. They occur always in the form of dykes and are completely devoid of picroilmenite and pyrope, though diamondbearing and sometimes very rich. One particularity is the relative abundance of spinels : ferromagnesian or chrome spinels at Seguela, chromite spinel in Gabon. They mineralize the alluvia in their vicinity and the subordinate drainage. Autometasomatism and perhaps dynamometamorphism in Gabon had completely transformed the original lamprophyric kimberlites into a kind of micaceous soapstone, and a late highly potassic phase is obvious at Seguela where fenitization occurs in the granitic walls, and sometimes a strange association with rare fitzroyite leucite rocks.

Seguela "metakimberlites"

In the center of Ivory Coast, the Seguela alluvial diamond field which produced about $2 \mathrm{M}$ ct derives from two main dykes systems, Toubabouko and Bobi.

The Toubabouko dyke, about one meter wide with a general $\mathrm{N}$ or NNW strike (a Precambrian direction) is more or less known along several kilometers and is intrusive in a Precambrian (1900 m.y) granite. The kimberlitic fabric of the soft rock is hardly seen as the olivine nodules are completely transformed into talc, with some calcite, and serpentine quite subordinate. There is much phlogopite; picroilmenite and pyrope are absent or the former has been leucoxenized and very fine. Apatite, zircon, magnetite can be seen, and an unusual Mn-Ilmenite (Pyrophanite), with traces of galena, sphalerite and scheelite, and.. diamond. Sometimes there is a marked fenitization of the granitic wall which, over a foot or more is transformed into a hyperalcaline syenite with high $\mathrm{K}_{2} \mathrm{O}$. Chloritization, epidotization and hematisation penetrates some meters deeper. At depth chloritization is more pronounced, but I do not think like KNOPF that this transformation result from the action of meteoric water but of metasomatism.

\title{
Bobi dykes
}

Ten miles to the East the thin, but very rich, Bobi dykes are inti- 
mately associated with lodes of a barren lamproite, which is more exactly a fitzroyite. Those very peculiar and rare leucitic volcanic rocks were described by WADE \& PRIDER (1929) in Western Australia and are kin to the wyomingites of USA and jumillites of Spain. They are rich in $\mathrm{Ba}$, Sr, $\mathrm{Zr}$ (sometimes $\mathrm{Nb}$ ) like kimberlites, and $\mathrm{Ti}, \mathrm{K}_{2} \mathrm{O}(10 \%)$, with low $\mathrm{Na}_{2} \mathrm{O}$. According to a study by the Overseas Geolo. Survey the Bobi lamproite contains, in $37 \%$ groundmass (phlogopite, leucite, chlorite and $\mathrm{SiO}_{2}$ ), $19 \%$ of altered leucite crystals, $24 \%$ of phlogopite, $10 \%$ of anatase, $4 \%$ of apatite etc. Chemical analysis is very close to that of PRIDER fitzroyite. It is interesting to note that this geologist had proposed a similar origin for kimberlites and fitzroyites, from a micaceous peridotitic magma, enriched in minor elements, $\mathrm{K}_{2} \mathrm{O}$ and $\mathrm{SiO}_{2}$ by the separation of olivine. In the lamproites this evolution was probably carried on for too long, under too low $\mathrm{P} / \mathrm{T}$ conditions, for the preservation of the magma diamonds. On the contrary, at Bobi, the contiguous kimberlite was kept very rich (up to $30 \mathrm{ct} / \mathrm{m}^{3}$ !). A same very rare association of kimberlite and lamproite had been found recently in the explosive structure of Mt Abbott ( $W$. Australia), and confirms PRIDER hypothesis. Seguela kimberlites had been dated by BARDET \& VACHETTE at $1429 \mathrm{~m} \cdot \mathrm{y}$ by the $\mathrm{Rb}-\mathrm{Sr}$ method.

\section{Mitzic Metakimberlites}

Near Mitzic (NW Gabon) many kimberlitic dykes had been recently discovered, and the possibility of a wider province from Equatorial Guinea to Brazzaville Congo (with the small Komono deposit) cannot be dismissed. Those mineralized dykes have a general NW trend following conspicuous fractures in the basement. The kimberlite, more schistose than at Seguela and which seems to have been crushed, is formed by $80 \%$ of talc, with relics of altered mica, some chlorite and prismes of tremolite-actinote, and contains many very small octahedrons of diamond. The nodular structure appears to result from dynamic deformations, and olivine relics are not recognizable. There is no ilmenite nor pyrope, but chromite is rather abundant and, found in the alluvia with diamonds, behaves as a good tracer. Like at Seguela the chemistry is quite characteristic of a kimberlite, with high $\mathrm{Ba}, \mathrm{Sr}$, V etc., elements which are absent from the Gabon M'Bigou Soapstones, in spite of some similarity with these rocks of a quite different origin. The age of Mitzic kimberlites is not known, but is obviously Precambrian and probably older than the base of Francevillian ( $1900 \mathrm{~m} \cdot \mathrm{y}$. or less ?) which contains diamonds.

\section{Conclusion}

Direct transformation of olivine into talc without serpentinization had been described by BOWEN, and some "talc-kimberlites" mentioned in Soviet literature, but not as a source of diamonds. In some regions of the world, diamond alluvial deposits occur which carry no specific kimberlitic minerals. To be sure, ilmenite and pyrope could have been completely destroyed mechanically and chemically during the long processes of erosion and transportation. But sometimes this evidence is lacking, and one could question the possibility of a "metakimberlitic" origin, especially when more resistant spinels are systematically associated with the diamonds. For example in some isolated Sierra-Leone diamond fields HALL (1970)suspected the existence of such an aberrant 
source, but did not succeed in proving it. Possibly in some Precambrian areas, diamond fields have been missed owing to the absence of the "classic" kimberlitic tracers and some intriguing problems could be rexamined with this point of view. This abnormal type of kimberlite deserves a better and deeper study.

Analysis (BRGM - Orléans)

Metakimberlite

Seguela, Toubabouko - Mitzic,Amié - Lamproite Bobi-Fitzroyite

\begin{tabular}{|c|c|c|c|c|c|c|c|}
\hline $\mathrm{SiO}_{2}$ & 57.80 & 56.40 & 54.60 & - & 50.3 & - & 52.45 \\
\hline $\mathrm{Al}_{2} \mathrm{O}_{3}$ & 0.80 & 1.50 & 2.95 & - & 8.2 & & 8.64 \\
\hline $\mathrm{Fe}_{2} \mathrm{O}_{3}$ & 1.90 & 2.60 & 5.40 & - & 7.4 & & 5.37 \\
\hline $\mathrm{FeO}$ & 2.90 & 3.10 & 2.50 & - & 0.2 & & 0.94 \\
\hline $\mathrm{TiO}_{2}$ & 1.45 & 1.60 & 0.93 & - & 5.7 & & 5.85 \\
\hline $\mathrm{CaO}^{2}$ & 1.30 & 1.80 & 0.60 & - & 2 & & 2.01 \\
\hline MgO & 25.90 & 26.10 & 26.85 & - & 9.8 & & 6.42 \\
\hline $\mathrm{Na}_{2} \mathrm{O}$ & 0.20 & 0.15 & 0.10 & - & 0.2 & & 0.38 \\
\hline $\mathrm{K}_{2} \mathrm{O}$ & 0.45 & 0.55 & 0.30 & - & 10 & & 10.42 \\
\hline $\mathrm{P}_{2} \mathrm{O}_{\underline{5}}$ & 0.30 & 0.40 & 0.30 & - & 2 & & 1.58 \\
\hline $\mathrm{H}_{2}^{2} \mathrm{O}^{-}$ & 1.50 & 1.20 & 0.25 & - & 0.45 & & 2.89 \\
\hline $\mathrm{H}_{2} \mathrm{O}^{+}$ & 2.80 & 4.50 & 5.40 & - & 1.85 & & 1.99 \\
\hline \multicolumn{3}{|l|}{$\overline{\mathrm{Ni}} \mathrm{ppm}$} & 1500 & $\mathrm{NiO}$ & 0.03 & & \\
\hline \multicolumn{3}{|l|}{$\mathrm{Cr}$} & 1150 & & & & \\
\hline \multicolumn{3}{|l|}{ Co } & 80 & & & & \\
\hline \multicolumn{3}{|l|}{$\mathrm{Ba}$} & 460 & $\mathrm{BaO}$ & 0.70 & $\mathrm{BaO}$ & 1.19 \\
\hline \multicolumn{3}{|l|}{ Sr } & 15 & Sro & 0.20 & & \\
\hline \multicolumn{3}{|l|}{ Sc } & 19 & & & & \\
\hline \multicolumn{3}{|l|}{ V } & 170 & & & & \\
\hline \multicolumn{3}{|l|}{$\mathrm{Pb}$} & 96 & & & & \\
\hline \multirow[t]{3}{*}{$\mathrm{Zn}$} & & & 250 & & & & \\
\hline & & & & $\mathrm{Zr02}$ & 20.3 & & \\
\hline & & & & $\mathrm{F}$ & 0.7 & & \\
\hline
\end{tabular}

\section{Bibliography}

BARDET M.G. - 1973 - "Géologie du Diamant". BRGM PARIS - Under Press.

BARDET M.G. \& VACHETTE M. - 1970 - "Détermination d'âges de kimberlites de l'Ouest Africain!' 3e Colloque de Géologie Africaine, BruxellesTervuren.

HALL P.K. - 1970 - "The Diamond Fields of S. Leone". SL Geol. Surv. Bull. $n^{\circ} 5$.

KNOPF D. - 1970 - "Les kimberlites et roches apparentées de Côte d'Ivoirë SODEMI - Abidjan - \& Thèse Lausanne.

PRIDER R.T. - 1960 - "The leucite lamproittes of the Fitzroy Basin W.A" Jl Geol. Sty Australia v. 6, Pt 21960.

WADE A. \& PRIDER R.T - 1939 - "The leucite-bearing rocks of the West Kimberleys Area-Western Australia" Quat. JI Geol. Sty V XCVI Pt 1. 